\title{
PENGARUH KEADAAN DEMOGRAFI SOSIAL EKONOMI TERHADAP MANAJEMEN KEUANGAN PRIBADI MELALUI LITERASI KEUANGAN PEGAWAI BLUD RSUD BAYUNG LENCIR
}

\author{
Radius Prawiro \\ Magister Manajemen Universitas Jambi \\ email: rathiusprawiro@gmail.com
}

\begin{abstract}
Abstrak.
Tujuan dari penelitian ini adalah untuk mengkaji Pengaruh variabel Kondisi Demografi Sosial Ekonomi berpengaruh terhadap Literasi Keuangan, Pengaruh variabel Literasi Keuangan berpengaruh terhadap Manajemen Keuangan Pribadi, mengkaji Pengaruh variabel Kondisi Demografi Sosial Ekonomi berpengaruh terhadap Manajemen Keuangan Pribadi dan melihat seberapa pentingnya peranan variabel literasi keuangan dalam memediasi antara variabel keadaan demografi sosial ekonomi terhadap manajemen keuangan pribadi. Metode penelitian yang akan digunakan dalam penelitian ini adalah metode deskriptif dan metode verifikatif. Dengan sampel sebanyak 38 Pegawai Negeri Sipil di BLUD RSUD Bayung Lencir yang di pilih menggunakan metode purposive sampling dari populasi seluruh pegawai BLUD RSUD Bayung Lencir. Metode penelitian yang digunakan menggunakan analisis Pengelolaan data pada penelitian ini akan menggunakan Software smartPLS 3.2.7. Hasil penelitian ini menunjukkan bahwa tidak terdapat pengaruh antara variabel Keadaan Demografi Sosial Ekonomi Terhadap Manajemen Keuangan Pribadi, sementara melalui variabel intervening memilikii Pengaruh yakni variabel Keadaan Demografi Sosial Ekonomi Terhadap Literasi Keuangan, dan hasil pengujian menunjukan pengaruh antara variabel literasi keuangan terhadap Manajemen Keuangan Pribadi, hasil pengujian yang dilakukan dengan menggunakan sobel menunjukan variabel literasi keuangan mampu menjadi variabel mediasi antara variabel Keadaan Demografi Sosial Ekonomi Terhadap Manajemen Keuangan Pribadi.
\end{abstract}

Kata Kunci $\quad$ : Keadaan Demografi Sosial Ekonomi, Literasi Keuangan, Manajemen Keuangan Pribadi

\begin{abstract}
The purpose of this study was to examine the influence of the variables of Socio-Economic Demographic Conditions that affect Financial Literacy, the influence of the Financial Literacy variable on Personal Financial Management, to examine the influence of the variables of Socioeconomic Demographic Conditions on Personal Financial Management and to see how important the role of the variable financial literacy is in mediating. between the variables of socioeconomic demographic conditions on personal financial management. The research method used in this research is descriptive method and verification method. With a sample of 38 Civil Servants at the Bayung Lencir Regional General Hospital BLUD which were selected using the purposive sampling method from the population of all BLUD Bayung Lencir Hospital employees. The research method used is analysis. Data management in this study will use SmartPLS 3.2.7 software. The results of this study indicate that there is no influence between the variables of the Demographic Socioeconomic State on Personal Financial Management, while through the intervening variable it has an influence, namely the Socio-Economic Demographic State variable on
\end{abstract}


Financial Literacy, and the test results show the influence of financial literacy variables on personal financial management Tests carried out using Sobel show that the financial literacy variable is able to be a mediating variable between the Socio-Economic Demographic State variables on Personal Financial Management.

Keywords: Socio-Economic Demographics, Financial Literacy, Management Personal Finance

\section{PENDAHULUAN}

Pengelolaan keuangan merupakan hal yang sangat penting dalam upaya mencapai kesejahteraan. Kegagalan dalam pengelolaan keuangan akan memicu munculnya masalah kesulitan keuangan yang selanjutnya akan berdampak pada kegagalan dalam mencapai kesejahteraan. Parrotta \& Johnson (1998) mengatakan bahwa kesulitan keuangan dan ketidakpuasan dengan status keuangan seseorang dapat menyebabkan konflik keluarga dan perceraian. Masalah pengelolaan keuangan dikenal dengan istilah manajemen keuangan personal (Personal financial management). Manajemen keuangan personal dapat didefinisikan sebagai suatu proses mengelola uang untuk mencapai kepuasan ekonomi atau kesejahteraan personal (Kapoor,Dlabay \& Hughes, 2012). Coalition for Personal Financial Literacy (2007) menjelaskan bahwa keuangan personal menggambarkan prinsip-prinsip dan metode-metode yang digunakan individu untuk mendapatkan dan mengelola pendapatan dan kekayaan.

Sesuai dengan pasal 1 butir (23). Undang-undang Nomor 1 Tahun 2004 tentang Perbendaharaan Negara disebutkan: "Badan Layanan Umum adalah instansi di lingkungan Pemerintah yang dibentuk untuk memberikan pelayanan kepada masyarakat berupa penyediaan barang dan/ atau jasa yang dijual tanpa mengutamakan mencari keuntungan dan dalam melakukan kegiatannya didasarkan pada prinsip efisiensi dan produktivitas." Penjelasan tersebut secara spesifik menunjukkan karakteriktik entitas yang merupakan Badan Layanan Umum, yaitu: a. Berkedudukan sebagai lembaga pemerintah yang tidak dipisahkan dari kekayaan Negara; b. Menghasilkan barang dan /atau jasa yang diperlukan masyarakat dan tidak bertujuan untuk mencari laba; c. Dikelola secara otonom dengan prinsip efisiensi dan produktivitas ala korporasi; d. Rencana kerja, anggaran dan pertanggungjawabannya dikonsolidasikan pada instansi induk; e. Penerimaan baik pendapatan maupun sumbangan dapat digunakan secara langsung; dan f. Pegawai dapat terdiri dari pegawai negeri sipil dan bukan pegawai negeri sipil. Apabila dikelompokkan menurut jenisnya Badan Layanan Umum terbagi menjadi 3 kelompok, yaitu: a. BLU yang kegiatannya menyediakan barang atau jasa meliputi rumah sakit, lembaga pendidikan, dan lain-lain; b. BLU yang kegiatannya mengelola wilayah atau kawasan meliputi otorita pengembangan wilayah dan kawasan ekonomi terpadu ; dan c. BLU yang kegiatannya mengelola dana khusus meliputi pengelolaan dana bergulir, dana UKM, dan lain-lain. Sehubungan dengan karakteristik yang spesifik, BLU dihadapkan pada peraturan yang spesifik pula dan berbeda dengan entitas yang merupakan kekayaan negara yang dipisahkan (BUMN/BUMD).

Perbedaan tersebut terletak pada hal-hal sebagai berikut: a. BLU dibentuk untuk meningkatkan pelayanan kepada masyarakat dalam rangka memajukan kesejahteraan umum dan mencerdaskan kehidupan bangsa; b. Kekayaan BLU merupakan bagian dari kekayaan negara/daerah yang tidak dipisahkan serta dikelola dan dimanfaatkan sepenuhnya untuk menyelenggarakan kegiatan BLU yang bersangkutan; c. Pembinaan BLU instansi pemerintah pusat dilakukan oleh Menteri Keuangan dan pembinaan teknis dilakukan oleh menteri yang bertanggung jawab atas bidang pemerintahan yang bersangkutan; d. embinaan keuangan BLU instansi pemerintah daerah dilakukan oleh pejabat pengelola keuangan daerah dan pembinaan teknis dilakukan oleh kepala satuan kerja perangkat daerah; e. Setiap BLU wajib menyusun rencana kerja dan anggaran tahunan dan rencana bisnis dan anggaran; f. Rencana Kerja dan Anggaran (RKA) serta laporan keuangan dan laporan kinerja BLU disusun dan disajikan sebagai bagian yang tidak terpisahkan dari RKA serta laporan keuangan dan laporan kinerja kementerian 
negara/lembaga/pemerintah daerah; g. Pendapatan yang diperoleh BLU sehubungan dengan jasa layanan yang diberikan merupakan pendapatan negara/daerah; h. Pendapatan tersebut dapat digunakan langsung untuk membiayai belanja yang bersangkutan; i. BLU dapat menerima hibah atau sumbangan dari masyarakat atau badan lain; dan j. Ketentuan lebih lanjut mengenai pengelolaan keuangan BLU diatur dalam peraturan pemerintah.

Dengan pemikiran baru tersebut diharapkan bukan bentuknya saja suatu unit pemerintah menjadi Badan Layanan Umum yang melayani masyarakat tetapi tingkat pelayanan masyarakat dapat ditingkatkan dengan cara yang profesional, efektif dan efisien oleh pengelola unit tersebut dengan otonomi pengelolaan. Kebijakan Pemerintah Republik Indonesia dengan PP No. 23 tahun 2005 mengenai Pengelolaan Keuangan Badan Layanan Umum mempunyai persyaratan persyaratan.Salah satu persyaratannya adalah adanya Rencana Strategis Bisnis. Ini artinya untuk anggaran pendapatan dan belanja yang bersumber dari BLUD telah menjadi hak otonomi sepenuhnya Rumah Sakit untuk memberikan pelayanan kepada masyarakat berupa penyediaan barang dan/atau jasa yang dijual tanpa mengutamakan mencari keuntungan dan dalam melakukan kegiatannya didasarkan pada prinsip efisiensi dan produktivitas. Keputusan Bupati Musi Banyuasin Nomor : 784/KPTS-DINKES/2016 Tentang Pola Pengelolaan Keuangan Badan Layanan Umum Daerah Rumah Sakit Bayung Lencir. Belanja Remunerasi yang dalam hal ini dimaksudkan Belanja Pegawai sebesar 40\% dari pagu anggaran dan $4 \%$ belanja pembayaran gaji pegawai dan 56\% Belanja Operasional yang terdiri dari Belanja Barang dan Jasa dan Belanja Modal. Keputusan Bupati Musi Banyuasin Nomor 100 Tahun 2019 Tentang Sistem Remunerasi Rumah Sakit.

Kenyataannya manusia senantiasa dihadapkan pada berbagai masalah, yang salah satunya masalah tersebut adalah masalah kesulitan keuangan. Banyak orang berpendapat bahwa penyebab munculnya masalah kesulitan keuangan semata-mata dipicu karena rendahnya tingkat pendapatan. Padahal tidak demikian, kesulitan keuangan bukan hanya semata-mata fungsi dari pendapatan (rendahnya pendapatan), kesulitan keuangan juga dapat muncul jika terjadi kesalahan dalam pengelolaan keuangan (financial management) seperti kesalahan dalam pengelolaan kredit dan tidak adanya perencanaan keuangan (Ayu dkk, 2010). Parrotta \& Johnson (1996) mendefinisikan pengelolaan keuangan (financial managenment) sebagai bentuk perilaku yang menyangkut perencanaan, implementasi dan evaluasi tentang kas, kredit, investasi, asuransi, dan perencanaan tingkat hidup dan perencanaan masa pensiun.

Secara umum, kurangnya pengetahuan keuangan dalam hal keterampilan keuangan diatas diakibatkan oleh pendidikan. Pengetahuan keuangan dapat diperoleh dari pendidikan formal dan sumber-sumber informal. Pendidikan formal ini seperti program sekolah tinggi atau kuliah, seminar, dan kelas pelatihan di luar sekolah. Sedangkan sumber-sumber informal dapat diperoleh dari lingkungan sekitar, seperti dari orang tua, teman, dan rekan kerja, maupun yang berasal dari pengalaman sendiri. Berdasarkan uraian tersebut dapat dikatakan pengetahuan keuangan para pelaku Apratur Sipil Negara sangat buruk.Terdapat masalah lain yang mempengaruhi perilaku manajemen keuangan yang dimiliki oleh para pelaku Pegawai BLUD RSUD Bayung Lencir, yaitu masalah mengenai sikap keuangan yang dimiliki. Kebanyakan pelaku Pegawai BLUD RSUD Bayung Lencirmemiliki sikap yang buruk mengenai keuangan, ditandai dengan rendahnya motivasi untuk terus meningkatkan kesejahteraan hidup dalam mengelola keuangan pendapatan, padahal Bila dilihat dari penghasilan mereka bukan menjadi rahasia umum lagi bahwa seharusnya sudah mampu memenuhi kehidupannya. adapun jumlah populasi pada penelitian ini dapat di lihat pada table berikut ini : 
Grafik 1.1

Pegawai BLUD RSUD Bayung Lencir

\section{Pegawai BLUD RSUD Bayung Lencir}

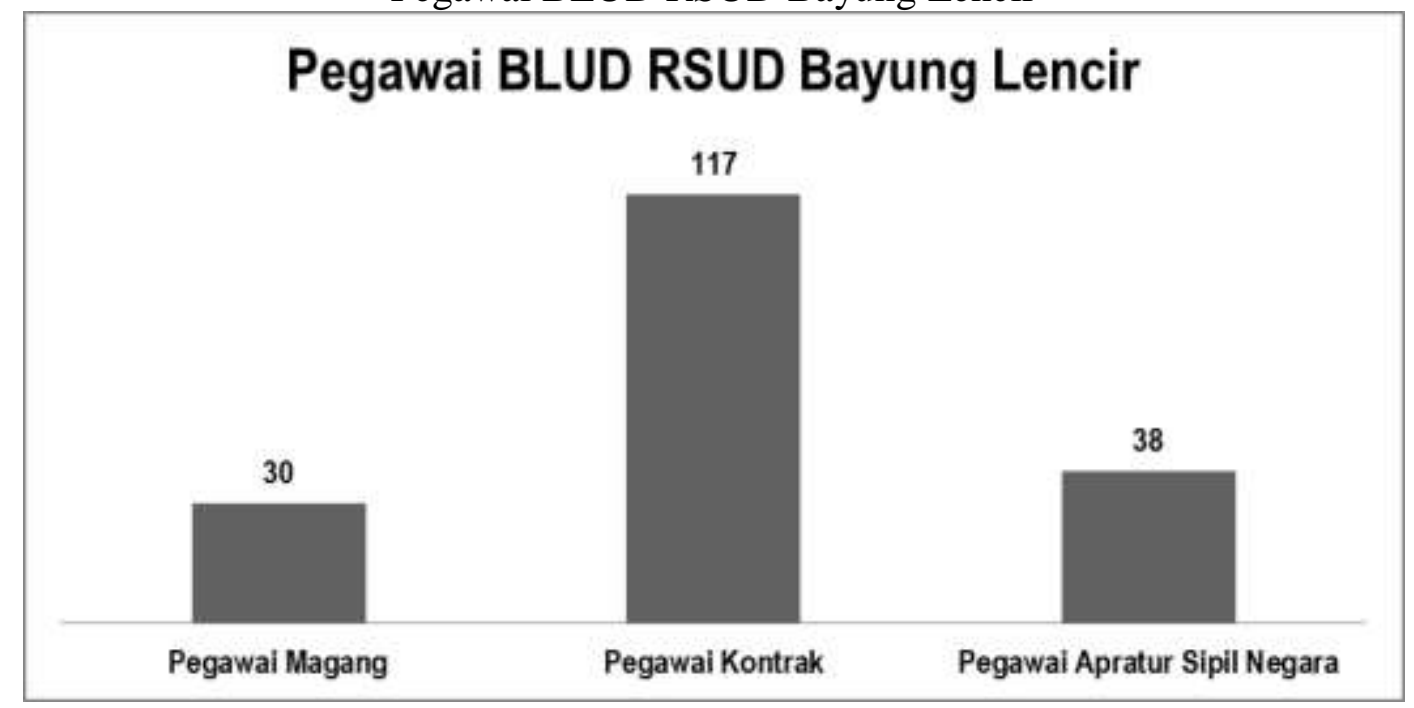

Sumber : Bagian Kepegawaian RSUD Bayung Lencir

Tingkat literasi keuanganmasyarakat atau kelompok masyarakatberbeda antara yang satu dengan yanglainnya.Perbedaan ini disebabkan, salahsatunya, karena adanya perbedaan Karakteristik Sosial Ekonomi atau banyak peneliti yang menyebutnya dengan Karakteristik Demografi. Penelitian ini dilakukan dengantujuan untuk mengkaji baik secara langsung maupun melalui variabel mediasi pengaruh variabel Keadaaan Demografi Sosial Ekonomi terhadap Manajemen Keuangan Personal, pengaruh variabel Karakteristik Demografi Sosial Ekonomi terhadap Lirtasi Keuangan dan pengaruh Lirtasi Keuangan terhadap Manajemen Keuangan Pribadi.

\section{METODE}

Metode penelitian yang akan digunakan dalam penelitian ini adalah metode deskriptif dan metode verifikatif. Metode deskriptif digunakan untuk menggambarkan atau mendeskripsikan literasi keuangan (pengetahuan keuangan, perilaku keuangan, dan sikap keuangan) dan karakteristik sosial ekonomi (pendidikan, jabatan dan penghasilan), dan manajemen keuangan personal Pegawai Negeri Sipil di RSUD Bayung Lencir kabupaten musi banyuasin.. Metode verifikatif digunakan untuk menjelaskan pengaruh variabel literasi keuangan (pengetahuan keuangan, perilaku keuangan, dan sikap keuangan) dan karakteristik sosial ekonomi (pendidikan, jabatan dan penghasilan) terhadap manajemen keuangan personal.

\section{HASIL DAN PEMBAHASAN}

Penelitian Ini mempunyai indikator yang bersifat reflektif dan Formatif. Menurut Chin (1998) analisis model pengukuran konstruk dengan indikator reflektif ingin melihat validitas dari masing-masing indikator dan menguji reliabilitas dari konstruk tersebut. Analisis model pengukuran untuk konstruk dengan indikator formatif dievaluasi atas dasar substantive content dan membandingkan signifikasi dari nilai estimasi weight (as cited in Ghozali, 2008). Hasil analisis statistik inferensial dalam penelitian ini mengikuti langkahlangkah pengujian empiris penelitian berbasis PLS 3.0.

\section{Hasil Pengujian Measurement Model (Outer Model) untuk Indikator Reflektif}


Keuangan dan Manajemen Keuangan Pribadi dianalisa menggunakan convergent validity masing-masing indikator. Hasil menunjukkan bahwa loading factor untuk konstruk Kondisi Ekonomi Sosial Ekonomi, Literasi Keuangan dan Manajemen Keuangan Pribadi ada yang dibawah 0,6 Oleh karena itu indikator-indikator ini tidak bisa berpengaruh antara Kondisi Ekonomi Sosial Ekonomi terhadap Literasi Keuangan Kondisi Ekonomi Sosial Ekonomi Terhadap Manajemen Keuangan Pribadi dan Literasi Keuangan Terhadap Manajemen Keuangan Pribadi.

Tabel 4.12

Composite Reliability 1

\begin{tabular}{|l|l|}
\hline & Composite Reliability \\
\hline KDSE & 0,581 \\
\hline LK & 0,726 \\
\hline MKP & 0,758 \\
\hline
\end{tabular}

Setelah membuang indikator refleksif yang tidak berpengaruh, maka dilakukan perhitungan kembali dan hasilnya adalah sebagai berikut:

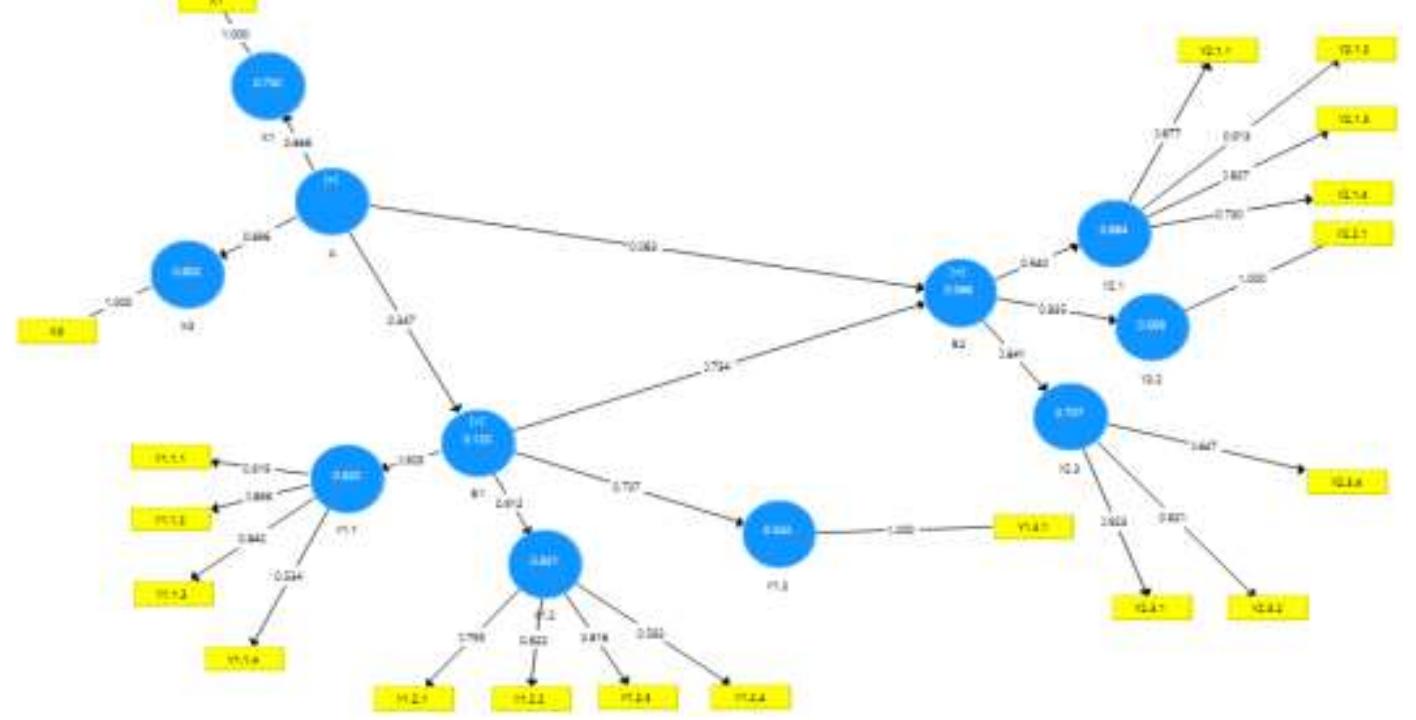

Gambar 4.2 Outer Model 2

Karena factor loading sudah terpenuhi, selanjutnya dilakukan uji composite reliability dan cronbach alpha.

Tabel 4.13

Composite Reliability 2

\begin{tabular}{|l|l|}
\hline & Composite Reliability \\
\hline KDSE & 0,874 \\
\hline LK & 0,903 \\
\hline MKP & 0,900 \\
\hline
\end{tabular}


Composite reliability dari ketiga variabel refleksif $>0,6$ sehingga reliabilitas dari konstruk variabel Kondisi Ekonomi Sosial Ekonomi, Literasi Keuangan dan Manajemen Keuangan Pribadi cukup tinggi.

Tabel 4.14

Cronbachs Alpha

\begin{tabular}{|l|l|}
\hline & Cronbach's Alpha \\
\hline KDSE & 0,712 \\
\hline LK & 0,877 \\
\hline MKP & 0,869 \\
\hline
\end{tabular}

Meskipun cronbach alpha variabel Kondisi Ekonomi Sosial Ekonomi, Literasi Keuangan dan Manajemen Keuangan Pribadi > 0,6, karena telah memenuhi composite reliability, maka variabel Kondisi Ekonomi Sosial Ekonomi, Literasi Keuangan dan Manajemen Keuangan Pribadi dapat dikatakan memiliki reliabilitas yang tinggi.

Langkah selanjutnya adalah mengetahui signifikansi masing-masing indikator terhadap konstruk variabel Kondisi Ekonomi Sosial Ekonomi, Literasi Keuangan dan Manajemen Keuangan Pribadi dengan melakukan bootstrapping dengan hasil sebagai berikut.

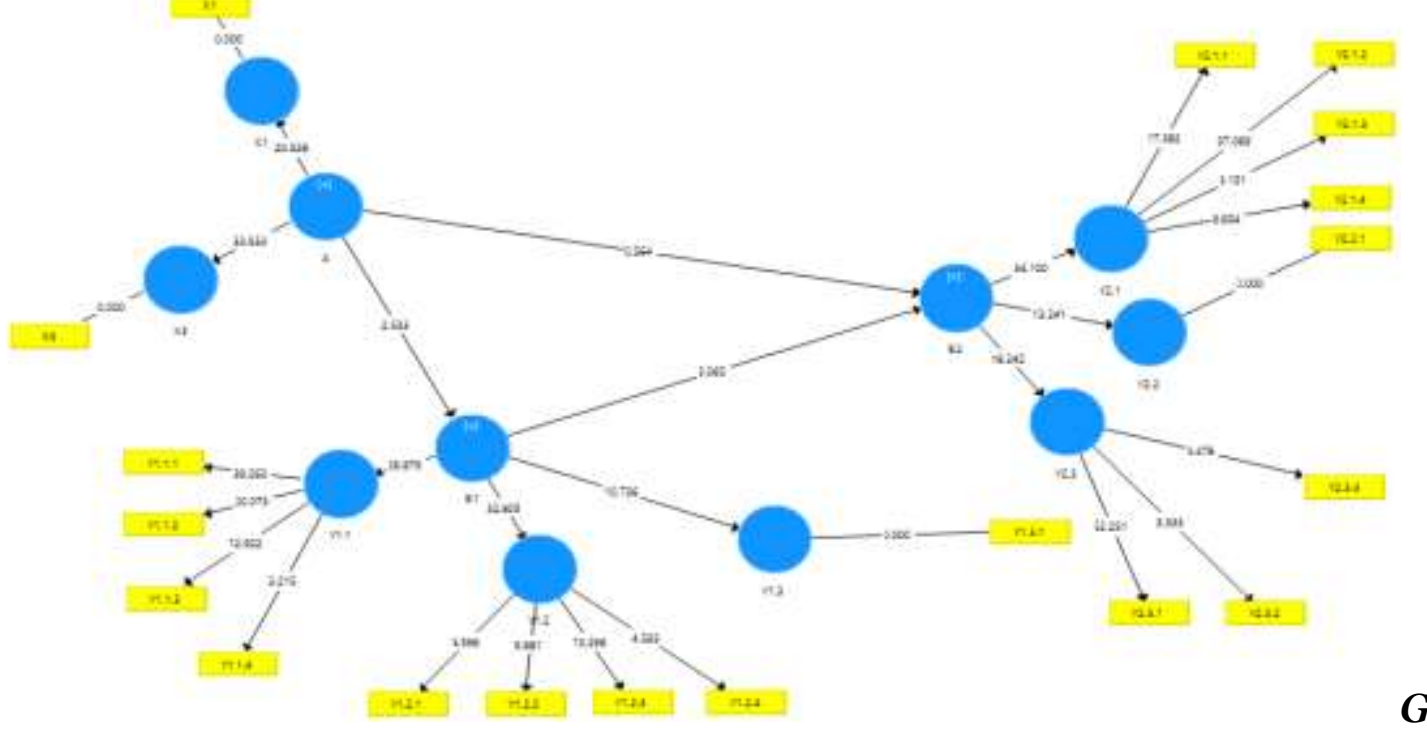

ambar 4.3 Hasil Bootstraping

Untuk melihat signifikansi/indikator terhadap model, dilakukan dengan melihat outer model indikator terhadap variabel bebas (X). Adapun hasil outer loading dapat dilihat pada gambar 4.3

Tabel 4.15

Hasil Outer Loading

\begin{tabular}{|l|l|}
\hline & T Statistics ([O/STDEV]) \\
\hline KDSE ->LK & 2,533 \\
\hline LK ->MKP & 9.065 \\
\hline KDSE->MKP & 20,328 \\
\hline
\end{tabular}


Berdasarkan nilai t-statistic pada tabel di atas, maka disimpulkan bahwa semua indikator adalah signifikan selain variabel Keadaan Demografi Sosial Ekonomi Terhadap Manajemen Keuangan Pribadi signifikan karena nilai t-statistic > 1,96 (Ghozali. 2008: 77) sedangkan variabel Keadaan Demografi Sosial Ekonomi melalui variabel intervending Literasi Keuangan Terhadap Manajemen Keuangan Pribadi berpengaruh signifikan karena memiliki nilai outer loading $=1$ pada seluruh dimensi signifikan karena memiliki nilai outer loading $=1$ Berdasarkan hasil olah data maka indikator variabel reflektif yang signifikan adalah, Keadaan Demografi Sosial Ekonomi melalui variabel intervending Literasi Keuangan Terhadap Manajemen Keuangan Pribadi berpengaruh signifikan.

\section{Hasil Pengujian Measurement Model (Outer Model) untuk Indikator Formatif}

Konstruk indikator variabel formatif tidak dapat dianalisis dengan melihat convergent validity dan composite reliability. Sehingga untuk melihatnya digunakanlah nilai outer weight masing-masing indikator dan nilai signifikansinya dapat dilihat pada gambar sebagai berikut :

Tabel 4.16

Outer Weight

\begin{tabular}{|l|c|}
\hline & T Statistics ([O/STDEV]) \\
\hline $\mathrm{X} 1<-\mathrm{X} 1$ & \\
\hline $\mathrm{X} 1<-\mathrm{KDSE}$ & 19,442 \\
\hline $\mathrm{X} 3<-\mathrm{X} 3$ & \\
\hline $\mathrm{X} 3<-\mathrm{A}$ & 15,941 \\
\hline $\mathrm{Y} 1.1 .1<-\mathrm{Y} 1.1$ & 9,756 \\
\hline $\mathrm{Y} 1.1 .1<-\mathrm{LK}$ & 9,989 \\
\hline $\mathrm{Y} 1.1 .2<-\mathrm{Y} 1.1$ & 13,088 \\
\hline $\mathrm{Y} 1.1 .2<-\mathrm{LK}$ & 14,058 \\
\hline $\mathrm{Y} 1.1 .3<-\mathrm{Y} 1.1$ & 12,547 \\
\hline $\mathrm{Y} 1.1 .3<-\mathrm{LK}$ & 9,647 \\
\hline $\mathrm{Y} 1.1 .4<-\mathrm{Y} 1.1$ & 3,187 \\
\hline $\mathrm{Y} 1.1 .4<-\mathrm{LK}$ & 2,880 \\
\hline $\mathrm{Y} 1.2 .1<-\mathrm{Y} 1.2$ & 7,806 \\
\hline $\mathrm{Y} 1.2 .1<-\mathrm{LK}$ & 6,261 \\
\hline $\mathrm{Y} 1.2 .2<-\mathrm{Y} 1.2$ & 8,128 \\
\hline $\mathrm{Y} 1.2 .2<-\mathrm{LK}$ & 9,109 \\
\hline $\mathrm{Y} 1.2 .3<-\mathrm{Y} 1.2$ & 7,650 \\
\hline $\mathrm{Y} 1.2 .3<-\mathrm{LK}$ & 8,227 \\
\hline $\mathrm{Y} 1.2 .4<-\mathrm{Y} 1.2$ & 4,862 \\
\hline $\mathrm{Y} 1.2 .4<-\mathrm{LK}$ & 5,364 \\
\hline $\mathrm{Y} 1.3 .1<-\mathrm{Y} 1.3$ & 7,666 \\
\hline $\mathrm{Y} 1.3 .1<-\mathrm{LK}$ & 10,108 \\
\hline $\mathrm{Y} 2.1 .1<-\mathrm{Y} 2.1$ & 6,852 \\
\hline $\mathrm{Y} 2.1 .1<-\mathrm{MKP}$ & \\
\hline & \\
\hline & \\
\hline
\end{tabular}




\begin{tabular}{|l|c|}
\hline $\mathrm{Y} 2.1 .2<-\mathrm{Y} 2.1$ & 12,228 \\
\hline $\mathrm{Y} 2.1 .2<-\mathrm{MKP}$ & 12,623 \\
\hline $\mathrm{Y} 2.1 .3<-\mathrm{Y} 2.1$ & 11,463 \\
\hline $\mathrm{Y} 2.1 .3<-\mathrm{MKP}$ & 9,590 \\
\hline $\mathrm{Y} 2.1 .4<-\mathrm{Y} 2.1$ & 10,845 \\
\hline $\mathrm{Y} 2.1 .4<-\mathrm{MKP}$ & 10,924 \\
\hline $\mathrm{Y} 2.2 .1<-\mathrm{Y} 2.2$ & \\
\hline $\mathrm{Y} 2.2 .1<-\mathrm{MKP}$ & 12,331 \\
\hline $\mathrm{Y} 2.3 .1<-\mathrm{Y} 2.3$ & 9,201 \\
\hline $\mathrm{Y} 2.3 .1<-\mathrm{MKP}$ & 12,241 \\
\hline $\mathrm{Y} 2.3 .2<-\mathrm{Y} 2.3$ & 3,341 \\
\hline $\mathrm{Y} 2.3 .2<-\mathrm{MKP}$ & 2,915 \\
\hline $\mathrm{Y} 2.3 .4<-\mathrm{Y} 2.3$ & 3,298 \\
\hline $\mathrm{Y} 2.3 .4<-\mathrm{MKP}$ & 3,073 \\
\hline
\end{tabular}

Seperti yang terlihat, pada tabel t-statitik seluruh indikator memiliki nilai t-statistic > 196 Sehingga semua indikator valid untuk mengukur konstruk Manajemen Keuangan Pribadi.

\section{Pengujian Inner Model (Model Struktural)}

Pengujian ini menguji hubungan antara konstruk variabel Keadaan Demografi Sosial Ekonomi Terhadap Manajemen Keuangan Pribadi melalui Literasi Keuangan.Pengujian terhadap model struktural dilaksanakan dengan melihat nilai RSquare yang diuji dengan goodness-fit model.

Tabel 4.17

$\mathrm{R}$ Square

\begin{tabular}{|l|l|l|}
\hline & Original Sampel $(\mathrm{O})$ & Sample Mean $(\mathrm{M})$ \\
\hline KDSE -> LK & 0,347 & 0,358 \\
\hline LK $>$ MKP & 0,734 & 0,733 \\
\hline KDSE -> MKP & 0,083 & 0,069 \\
\hline
\end{tabular}

Dalam hal ini tabel R-Square di atas berfungsi untuk melihat peran/kontribusi pengaruh dari variabel Kondisi Demografi Sosial Ekonomi beserta dimensinya terhadap Manajemen Keuangan Pribadi melalui variabel Literasi Keuangan. Berdasarkan nilai RSquare sebesar 0.347, dapat disimpulkan bahwa kontribusi pengaruh dari variabel Keadaan Demografi Sosial Ekonomi beserta dimensinya terhadap Literasi Keuangan beserta dimensinya sebesar $34.7 \%$, atau variabilitas Literasi Keuangan beserta dimensinya yang dapat dijelaskan oleh indikator Kondisi Demografi Sosial Ekonomi adalah sebesar $34.7 \%$ sedangkan sisanya dijelaskan oleh variabel lain diluar yang telah diteliti. Sementara Berdasarkan variabel intervening nilai R-Square variabel Literasi Keuangan Terhadap Manajemen Keuangan Pribadi sebesar 0.734, dapat disimpulkan bahwa kontribusi pengaruh dari variabel Literasi Keuangan beserta dimensinya terhadap Manajemen Keuangan Pribadi beserta dimensinya sebesar $73.4 \%$. 
Namun secara langsung variabel Kondisi Demografi Sosial Ekonomi Terhadap Manajemen Keuangan Pribadi dengan nilai R-Square 0.083, dapat disimpulkanbahwa kontribusi pengaruh secara langsung variabel Kondisi Demografi Sosial Ekonomi Terhadap Manajemen Keuangan Pribadi sebesar 0.83\%.

Uji yang kedua adalah melihat signifikansi pengaruh variabelDemografi Sosial Ekonomi Terhadap Manajemen Keuangan Pribadi melalui Literasi Keuangan, dengan melihat nilai koefisien parameter dan nilai signifikansi t-statistik yang digambarkan dalam hasil sebagai berikut :

Tabel 4.18

Path Coefisien 1

\begin{tabular}{|l|l|l|}
\hline & T Statistics ([O/STDEV]) & P Values \\
\hline KDSE -> LK & 2,533 & 0,012 \\
\hline LK $->$ MKP & 9,065 & 0,000 \\
\hline KDSE -> MKP & 0,564 & 0,573 \\
\hline
\end{tabular}

Berdasarkan hasil analisis, diketahui bahwa nilai t-statistik antara pengaruh Keadaan Demografi Sosial Ekonomi dengan Literasi Keuangan adalah 2.533sedangkan untuk variabel Literasi Keuangan dengan Manajemen Keuangan Pribadi sebesar 9.065.sementara secara langsung Keadaan Demografi Sosial Ekonomi dengan Manajemen Keuangan Pribadi sebesar0.564.

Karena nilai variabel Keadaan Demografi Sosial EkonomiterhadapLiterasi Keuangan> 1,96 (Ghozali, 2008:77) maka variabel Keadaan Demografi Sosial Ekonomi dengan Literasi Keuanganberpengaruh dengan nilai 2.533 atau $2.53 \%$.

Sementara variabel Literasi Keuangan terhadap Manajemen Keuangan Pribadi > 1,96 (Ghozali, 2008:77) maka variabel Literasi Keuangan terhadap Manajemen Keuangan Pribadi berpengaruh denagn nilai 9.065 atau $9.06 \%$.

Namun secara langsung Keadaan Demografi Sosial Ekonomiterhadap Manajemen Keuangan Pribadi < 1,96 (Ghozali, 2008:77) maka variabel Keadaan Demografi Sosial Ekonomiterhadap Manajemen Keuangan Pribadi secara langsung tidak berpengaruh dengan nilai 0.564 atau $0.56 \%$.

\section{Uji Sobel}

Dalam uji sobel ini digunakan untuk mengetahui pengaruh variabel mediasi yaitu kepuasan. Menurut Baron dan Kenny (1986) dalam Ghazali (2011) suatu variabel disebut intervening jika variabel tersebut ikut mempengaruhi hubungan antara variabel independen dan variabel dependen.

Tabel 4.19

Path Coefisien 2

\begin{tabular}{|l|l|l|}
\hline & Original Sampel $(\mathrm{O})$ & Standard Deviation (STDEV) \\
\hline KDSE ->LK & 0,347 & 0,137 \\
\hline LK ->MKP & 0,734 & 0,081 \\
\hline
\end{tabular}

Tabel 4.20 
Sobel Test

\begin{tabular}{|l|l|r|l|l|l|}
\hline & Input & & Test statistic : & Std Error : & $P$-value : \\
\hline$A$ & 0,347 & Sobel test & 2,43935014 & 0,10441223 & 0,0147137 \\
\hline$B$ & 0,734 & Aroian test & 2,42568883 & 0,10500028 & 0,01527936 \\
\hline$S_{a}$ & 0,137 & Goodman test & 2,4532449 & 0,10382086 & 0,01415739 \\
\hline$S_{b}$ & 0,081 & Reset all & \multicolumn{3}{|c|}{ Calculate } \\
\hline
\end{tabular}

Hasil uji sobel lebih kecil dari nilai alfa 0,05 yakni sebesar 0,0147137 sehingga dapat disimpulkan bahwa Variabel Literasi Keuangan mampu memediasi antara Variabel Keadaan Demografi Sosial Ekonomi ke Variabel Manajemen Keuangan Pribadi. Penelitian ini senada dengan Hasil penelitian yang di lakukan Riantira Purnama Putri : 2017 menunjukkan faktor-faktor demografi memiliki pengaruh langsung dan tidak langsung terhadap perilaku keuangan pelaku ukm di makassar dengan literasi keuangan sebagai variabel intervening.

\section{Pembahasan}

Keadaan Demografi Sosial Ekonomi terhadap Manajemen Keuangan Pribadi memiliki pengaruh yang signifikan Berdasarkan analisis yang telah dilakukan melalui PLS maka didapatkan hasil bahwa variabelKeadaan Demografi Sosial Ekonomi berpengaruh Signifikan terhadap Literasi keuangan karena nilai variabel Keadaan Demografi Sosial Ekonomi > 1,96 (Ghozali, 2008:77) dengan demikian H1 diterima. Ini dapat disimpulkan bahwa adanya pengaruh yang signifikan dari Keadaan Demografi Sosial Ekonomi terhadap Manajemen Keuangan Pribadi pegawai BLUD RSUD Bayung Lencir.

Dari hasil hipotesis 2, dapat diketahui bahwa Variabel Literasi Keuangan mempunyai pengaruh yang signifikan terhadap Manajemen Keuangan Pribadi pada Pegawai RSUD BLUD Bayung Lencir. Berdasarkan analisis yang telah dilakukan melalui PLS maka didapatkan hasil bahwa dengan variabel intervening Literasi Keuangan mempengaruhi Manajemen Keuangan Pribadi karena karena nilai t-statistik variabel Literasi Keuangan > 1,96. ini berarti untuk mengalokasikan anggaran Pendapatan dan Belanja di perlukan pengetahuan, Prilaku dan Sikap terhadap Keuangan Pribadi agar arus kas yang di terima dan di keluarkan terarah juga untuk di masa mendatang dengan cara investasi yang tepat berdasarkan pengetahuan keuangan dalam hal ini beberapa Pegawai RSUD BLUD Bayung Lencir masih kurang pemehaman mengenai Literasi Keuangan sehingga masih saja terjerat hutang berjangka demi memenuhi kebutuhan yang bukan konsumtif. Sehingga dapat di simpulkan hasil penelitian ini adalah pengaruh variabel Keadaan Demografi Sosial Ekonomi mempunyai pengaruh signifikan terhadap variabel Literasi Keuangan.

Dalam penelitian ini dapat diketahui bahwa tidak terdapat pengaruh secara langsung Variabel Karakteristik Demografi Sosial Ekonomi berpengaruh terhadap Manajemen Keuangan Pribadi pada Pegawai RSUD BLUD Bayung Lencir. Berdasarkan analisis yang telah dilakukan melalui PLS maka didapatkan hasil bahwa variabel Keadaan Demografi Sosial Ekonomi secara langsung tidak mempengaruhi Manajemen Keuangan Pribadi karena nilai variabel keuangan < 1,96 (Ghozali, 2008:77) dengan demikian H3 ditolak. Dapat disimpulkan bahwa tidak adanya pengaruh secara langsung Variable karakteristik Demografi Sosisal Ekonomi terhadap Manajemen Keuangan Pribadi pada Pegawai RSUD BLUD Bayung Lencir. 
Berdasarkan hasil penelitian, dapat diketahui bahwa variabel Literasi Keuangan memiliki pengaruh antara variabel Karakteristik Demografi Sosial Ekonomi terhadap Manajemen Keuangan Pribadi, dan dasarkan analisis yang telah dilakukan melalui Uji Sobel yaitu nilai variabel Literasi Keuangan melalui pengujian sobel lebih kecil dari nilai alfa 0,05 yakni sebesar 0,0147137 maka didapatkan hasil bahwa variabel Literasi Keuangan mampu menjadi variabel Penengah antara variabel Karakteristik Demografi Sosial Ekonomi terhadap Manajemen Keuangan Pribadi. Dapat disimpulkan bahwa variabel Literasi Keuangan memiliki pengaruh yang signifikan antara variabel Karakteristik Demografi Sosial Ekonomi terhadap Manajemen Keuangan Pribadi.

\section{Simpulan Dan Saran}

\section{Simpulan}

1. Karakteristik sosial ekonomi sangat berpengaruh terhadap Pengetahuan keuangan (financial knowledge). Tinggi rendahnya pengetahuan keuangan (financial knowledge) seseorang ditentukan oleh keterkaitan atau interaksi karakteristik sosial ekonomi yang dimiliki orang tersebut, yaitu interaksi antara karakteristik usia, jenis kelamin, tingkat pendidikan, tempat tinggal, golongan gaji, dan tingkat pendapatan. Tingkat pendidikan merupakan variabel yang sangat mempengaruhi tinggi rendahnya pengetahuan keuangan (financial knowledge). Semakin tinggi tingkat pendidikan seseorang semakin tinggi tingkat pengetahuan tentang keuangannya. Sementara variabel umur, jenis kelamin, tempat tinggal, golongan gaji dan pendapatan tidak terlalu menentukan tinggi rendahnya tingkat pengetahuan keuangan (financial knowledge).

2. Karakteristik sosial ekonomi sangat berpengaruh terhadap perilaku keuangan (financial behavior). Baik buruknya perilaku keuangan (financial behavior) seseorang ditentukan oleh keterkaitan atau interaksi karakteristik sosial ekonomi yang dimiliki orang tersebut, yaitu interaksi antara karakteristik usia, jenis kelamin, tingkat pendidikan, tempat tinggal, golongan gaji, dan tingkat pendapatan. Tingkat pendidikan dan tempat tinggal merupakan variabel yang sangat mempengaruhi baik buruknya perilaku keuangan (financial behavior). Semakin tinggi tingkat pendidikan seseorang semakin baik perilaku keuangannya (financial behavior), dan orang yang tinggal diperkotaan menunjukkan perilaku keuangan yang lebih baik dibanding dengan orang yang tinggal di pedesaan. Sementara variabel umur, jenis kelamin, golongan gaji dan pendapatan tidak terlalu menentukan baik buruknya perilaku keuangan (financial behavior). Karakteristik sosial ekonomi sangat mempengaruhi baik buruknya sikap keuangan (financial attitude). Baik buruknya sikap keuangan (financial attitude) seseorang ditentukan oleh keterkaitan atau interaksi karakteristik sosial ekonomi yang dimiliki orang tersebut, yaitu interaksi antara karakteristik usia, jenis kelamin, tingkat pendidikan, tempat tinggal, golongan gaji, dan tingkat pendapatan.

3. Tingkat pendidikan dan tempat tinggal merupakan variabel yang sangat mempengaruhi baik buruknya sikap keuangan (financial attitude). Semakin tinggi tingkat pendidikan seseorang semakin baik sikap keuangannya (financial behavior), dan orang yang tinggal diperkotaan menunjukkan sikap keuangan yang lebih baik dibanding dengan orang yang tinggal di pedesaan. Sementara variabel umur, jenis kelamin, golongan gaji dan pendapatan tidak terlalu menentukan baik tidaknya sikap keuangan (financial attitude).

4. Literasi keuangan yang merupakan kombinasi dari pengetahuan keuangan (financial knowledge), perilaku keuangan (financial behavior) dan sikap keuangan (financial 
attitude) sangat mempengaruhi baik buruknya manajemen keuangan personal. Baik buruknya manajemen keuangan personal seseorang ditentukan oleh adanya keterkaitan dan interaksi diantara pengetahuan (knowledge), perilaku (behavior) dan sikap (attitude) keuangannya. Pengetahuan keuangan (financial knowledge), perilaku keuangan (financial behavior) dan sikap keuangan (financial attitude), ketiganya merupakan variabel yang sangat mempengaruhi baik buruknya manajemen keuangan personal. Semakin tinggi dan baik tingkat pengetahuan, perilaku, dan sikap keuangan seseorang akan semakin baik manajemen keuangan personalnya.

\section{Saran}

Berdasarkan hasil penelitian-penelitian terdahulu, menyatakan bahwa tingkat kesejahteraan bukan hanya merupakan fungsi dari pendapatan. Tingkat kesejahteraan tidak hanya ditentukan oleh besar kecilnya pendapatan, melainkan ditentukan juga oleh bagaimana individu bisa mengelola (memanage) keuangan personalnya. Karena hasil penelitian menunjukkan masih rendahnya tingkat manajemen keuangan personal PNS, Untuk itu disarankan bagi PNS khususnya dan masyarakat umumnya untuk bisa mengelola keuangan personalnya dengan baik terutama dalam pengelolaan kas, pengelolaan kredit, perencanaan untuk menghadapi masa pensiun, pengelolaan resiko, dan pengelolaan keuangan secara umum. Di Indonesia masalah manajemen keuangan personal ini belum banyak dikenal (menjadi perhatian) masyarakat, bagi pemerintah atau pemangku kepentingan, dalam upaya meningkatkan kesejahteraan masyarakat disarankan untuk melakukukan program sosialisasi manajemen keuangan personal kepada masyarakat, yang salah satunya bisa dilakukan dengan cara memasukan kajian manajemen keuangan personal dalam kurikulum pendidikan.

Hasil penelitian menunjukkan bahwa manajemen keuangan personal dipengaruhi oleh literasi keuangan (financial knowledge, financial behavior, dan financial attitude) dan yang mempengaruhi literasi keuangan salah satunya adalah tingkat pendidikan, maka disarankan bagi pemerintah atau para pemangku kepentingan untuk melakukan program pendidikan (educational program) yang menyangkut masalah literasi keuangan, seperti yang telah dilakukan di negara-negara lain. Penelitian ini dilakukan dalam lingkup masyarakat yang terbatas, yaitu di kalangan PNS dan variabel yang diteliti juga masih sangat terbatas sehingga perlu dilakukan penelitian lanjutan. Untuk itu bagi penelitipeneliti lainnya yang berminat meneliti hal yang sama, disarankan untuk melakukan penelitian dalam lingkup masyarakat yang lebih luas dan dengan variabel yang lebih banyak. Saat ini belum banyak literatur yang membahas masalah manajemen keuangan personal dan literasi keuangan, khususnya di Indonesia, untuk itu diharapkan hasil penelitian ini bisa menjadi bahan literatur bagi yang memerlukan dan dapat menjadi sumbangan dalam pengembangan dunia keilmuan.

\section{DAFTAR PUSTAKA}

Amanita Novi Yushita (2017). "Pentingnya Literasi Keuangan Bagi Pengelolaan Keuangan Pribadi”. Jurnal Nominal / Volume VI Nomor 1 / Tahun 2017

Baiq Fitriarianti (2018). "Pengaruh Literasi Keuangan, Perilaku Keuangan Dan Pendapatan Terhadap Keputusan Berinvestasi".

Faridhatun Faidah (2019). "Pengaruh Literasi Keuangan Dan Faktor Demografi Terhadap Minat Investasi Mahasiswa". F. Faidah / Journal of Applied Business and Economic Vol. 5 No.3 (Maret 2019) 251-263 
Febrina Hutabarat (2018). "Pengaruh Literasi Keuangan Dan Financial Technology Terhadap Inklusi Keuangan Pada Masyarakat Jabodetabek".

Herma Wiharno (2015). "Karakteristik Sosial Ekonomi Yang Mempengaruhi Literasi

Keuangan Serta Dampaknya Terhadap Manajemen Keuangan Personal".JRKA Volume 1 Isue 2.

Indriana Rezkia Putri, Abel Tasman (2019). "Pengaruh Financial Literacy dan Income terhadap Personal Financial Management Behavior pada Generasi Millennial Kota Padang". Jurnal Kajian Manajemen dan Wirausaha Volume 01 Nomor 012019 ISSN: Online 2655-6499.

Irin Widayati (2014). "Pengaruh Status Sosial Ekonomi Orang Tua, Pendidikan Pengelolaan Keuangan Keluarga, dan Pembelajaran di Perguruan Tinggi terhadap Literasi Finansial Mahasiswa". Jurnal Pendidikan Humaniora Vol. 2 No. 2, Hal 176-183

Poppy Alvianolita Sanistasya, Kusdi Rahardjo, Mohammad Iqbal (2019). "Pengaruh Literasi Keuangan dan Inklusi Keuangan Terhadap Kinerja Usaha Kecil di Kalimantan Timur". Jurnal Economia, Volume 14, Nomor 1, April 2019, 48-59. 